\title{
JaPANESE LANGUAge EducATION AND DysLeXIA: ON the NeCESSity Of THE Dyslexia ResearCh
}

\author{
Nagisa MORITOKI ŠKOF \\ University of Ljubljana, Slovenia \\ nagisa.moritoki@guest.arnes.si
}

\begin{abstract}
The purpose of this paper is to show the important role of dyslexia, which is said to account for most learning disabilities in Japanese language education. Potential dyslexic learners in Japanese language are rather few, however, the recognition of dyslexia brings about both the reform of Japanese language education as well as the results of the change to 'more accurately conceptualized as an alternative developmental pathway' (OECD 2007 92).

In this paper, I will first discuss what dyslexia is and what perspective it offers to the area of Japanese language education. I will then outline the present status of accepting and arranging learning disabilities and dyslexic learners in Japan and Japanese language education. Then I will consider actual conditions and attitudes about learning disabilitites and dyslexia in Japanese language education through previous surveys and point out present problems and finally proposals to solve them.

Dyslexia is a disability of the phonological component bound to semantic understandings, but includes future suggestions in widespread subjects to Japanese language education.
\end{abstract}

Keywords: dyslexia; Japanese; language learning; inclusive education; autonomous learning

\section{Povzetek}

Namen te raziskave je prikazati pomembnost prepoznavanja disleksije, ki naj bi bila vzrok za večino težav tudi $v$ procesu izobraževanja japonskega jezika. Kljub temu, da je učencev z disleksijo relativno malo, pa je njeno prepoznavanje spodbudilo reforme $v$ sistemu poučevanja japonskega jezika, rezultati pa se kažejo tudi $v$ 'spremembah konceptualizacije disleksije kot alternativne razvojne poti' (OECD 2007: 92).

$\checkmark$ raziskavi najprej predstavim pojav disleksije in diskutiram o vplivih, ki jim ima disleksija na področje izobraževanja japonskega jezika. Kasneje se osredotočim na sedanje dojemanje in razvrščanje učnih motenj ter dislektičnih učencev na primeru Japonske in pri izobraževanju japonskega jezika. Hkrati skozi predhodnje raziskave ocenjujem trenutne razmere in splošni odnos do učnih motenj, še posebej odnos do disleksije, izpostavljam problem in navajam predloge $\mathrm{k}$ reševanju problemov.

Ključne besede: disleksija; japonščina; učenje jezika; vključujoče izobraževanje; samostojno učenje 


\section{Introduction}

The statistics of the Japan Foundation 2013 count approximately four million Japanese language learners enrolled in institutions. These statistics do not include those engaged in civil language courses, TV/radio language courses, and learners who learn through the Internet or a social network system (SNS), which has grown in worldwide popularity in recent years. The diversification of such increasing number of learners includes varied purposes of learning, attributes of learners, learning environments, learners' backgrounds and so on. Considering this, the increasing number of learners with LDs (learning disabilities) is a present issue in Japanese language education (Ikeda, 2004; Imura, 2007; Ikeda and Moritoki, 2013 and others). In December 2004, 137 examinees (among them, 11 people with LDs) received special arrangements $^{1}$ on the JLPT (Japanese-Language Proficiency Test) ${ }^{2}$. Though only a small number among all examinees received such exemptions, this figure is steadily increasing every year.

The purpose of this paper is to show the importance of perspective of dyslexia, which is said to account for most LDs in Japanese language education. The next section first discusses what dyslexia is and what perspective it offers to Japanese language education. I will then outline the present status of accepting and arranging LD and dyslexic learners in Japan and Japanese language education in section 3 . In the following section, I will consider actual conditions and attitudes about LDs and dyslexia in Japanese language education through previous surveys and point out present problems and proposals to solve them.

\section{Learning disabilities, dyslexia and its cause}

Dyslexia is the most common and most carefully studied-of the learning disabilities; it affects $80 \%$ of all individuals identified as learning disabled (Lerner, 1989; Shaywitz, 2003; Shaywitz and Shaywitz, 2004; Ishii, 2004; OECD, 2007). Dyslexia is reported to affect $5-10 \%$ of alphabetic language speakers ${ }^{3}$. In Slovenia $3 \%$ of the population is seriously affected and $7 \%$ mildly. In addition, $2-3 \%$ of pupils categorized as serious cases are unable to finish elementary education because of dyslexia (Kavkler, 2002). However, with wider recognition and understanding of dyslexia in recent times, more dyslexics are being identified, recognized and counted in surveys. We cannot neglect

\footnotetext{
1 JLPT, Data of the test in December 2014. Retrieved from https://www.jpt.jp/statistics/pdf/2014_2_4.pdf

${ }^{2}$ The Japanese Language Proficiency Test (JLPT) is a test to measure and certify the Japaneselanguage proficiency of non-native speakers. It started under the joint organization of the Japan Foundation and Japan Educational Exchanges and Services (previously Association of International Education, Japan). It is the largest Japanese-language test in the world, with approximately 610,000 examinees in 62 countries and areas worldwide in 2011.

(http://www.jlpt.jp/e/about/message.html)

${ }^{3}$ BBC NEWS on September 1, 2004, Retrieved from http://news.bbc.co.uk/2/hi/health/3618060.stm
} 
the approximate $10 \%$ of the population identified as dyslexic. Considering this, we can safely estimate that the same ratio of Japanese language learners could be dyslexic in Europe.

Here, let us understand the definition of dyslexia. The definition below was given by the American organization International Dyslexia Association (IDA) in 2002, which has become the fundamental basis in Japan and other countries:

Dyslexia is characterized by difficulties with accurate and/or fluent word recognition and by poor spelling and decoding abilities. These difficulties typically result from a deficit in the phonological component of language that is often unexpected in relation to other cognitive abilities and the provision of effective classroom instruction. Secondary consequences may include problems in reading comprehension and reduced reading experience that can impede growth of vocabulary and background knowledge (adopted by the IDA Board of Directors, Nov. 12, 2002).

Dyslexia is considered to have a neurobiological foundation. The deficit of writing and reading abilities causes difficulties in reading comprehensions, therefore reducing reading experience, and thus, can lead to poor vocabulary and background knowledge. Dyslexia occurs developmentally, which is inherent or found in the stage of development, and acquirementally, which occurs because of accident or illness after the birth. We will discuss developmental dyslexia, since all of the Japanese examinees who have so far requested special arrangements for the JLPT are identified as developmental dyslexic.

The Japanese definition of dyslexia (Uno et al., 2006) is based on IDA's definition, however, it differs from IDA on the following two points. One is that the Japanese definition states deficit of the visual component, as well as the phonological one, which causes difficulties in accuracy and fluency of spelling and decoding in information progresses. It is reasonable to say that the process of reading and understanding differs among languages, for example between phonogram and ideogram, in a system of decoding characters and understanding meanings. The second characteristic point of the Japanese definition is that it refers to the mental status of dyslexics. The dyslexia often causes low self-evaluation and loss of confidence through repeated failures, and thus maladjustment to the society. Therefore, arrangements for dyslexics require both learning support and mental support. I will discuss the differences between the IDA's definition and Japanese definition in another paper.

\footnotetext{
${ }^{4}$ Retrieved from http://eida.org/definition-of-dyslexia/
} 


\section{Dyslexia in Japan and Japanese language education}

\subsection{Japanese students with LD and dyslexia in educational institutions}

The terms LD and dyslexia or 'yomikaki shōgai' (disabilities in reading and writing) have become quite common in recent years in Japan and Japanese language education because of the media and the increasing number of LD and dyslexic pupils. With the wide recognition of LDs and dyslexia, the number is reportedly increasing in Japan. According to the Ministry of Education, Culture, Sports, Science and Technology (MEXT) in Japan, diagnosed LDs have increased from 4.5\% (2003 survey) to $6.5 \%$ (2012 survey) and dyslexic students account for $4.5 \%$ (2012 survey) of approximately 53,000 children in compulsory education in Japan.

On the other hand, the Japan Student Services Organization (JASSO) survey (2015) was implemented in questionnaire format to approximately 1000 institutions in higher education and reported that $0.44 \%$ of students need special support in their studies. Students with developmental disorder (including LD, ADHD, high functioning autism and so forth) occupy almost $25 \%$ of the whole. Comparing the JASSO survey with the MEXT survey of 2012, it is estimated that quite a few students are learning without any special support at the higher education level, even if not all the disabled students go on to university. The survey also reports that 639 out of 833 schools that disabled students are enrolled in are carrying out special support for them.

Those surveys present recent changes in the status of students with difficulties in Japanese education. Japanese students with difficulties at educational institutions are counted less than in Europe, but are still certainly increasing. The survey reports that at least three-fourths of Japanese higher educational institutions have a support system for students with difficulties. Japanese goverment declaired 'Plan for 300,000 exchange students' by 2020, and considering such an increase of foreign students at the level of higher educations, foreign students' success on study in Japan will definitely depend much on firm support system for diversifying students at universities.

\subsection{Special arrangements on the JLPT}

Special arrangements on the JLPT for Japanese learners were first organized for an examinee with disabilities in 1994 when a Brazilian with cerebral palsy made a demand of his helper's attendance during the test. As for LDs, in 1996 a British examinee requested special arrangements for taking the JLPT. This was also a time when LDs came to be accepted in Japan. In 1992, the Ministry of Education, Science and Culture in Japan (at the time) established the Council of Research Cooperator on Teaching Methods of Students in Compulsory Education with LDs and Similar Difficulties, and it defined LD in 1999. MEXT, the former Ministry of Education, renamed 'special education' 'special support education'. The existing law is the Act on Support for Persons with Development Disabilities, implemented in 2005 in the 
general society; consequently, the revised School Education Act was enforced in 2007.

Let us have a look at the procedure of examinees and arrangements on the JLPT. The guidelines for special arrangements on the JLPT were established and carried out in 1999 (Ueda, 2003). Examinees with disabilities are to submit the Special Arrangements Request Form and an explanation of their disability written by a teacher from their current or former educational institution, or certified specialist such as a medical doctor or a case worker when they register their JLPT application. The committee at the JLPT head office examines the form sent from the examinee, accepts/revises to accept, and informs the local institution to let the examinee take the test with appropriate measures. After taking the exam, the local institution and the examinee report whether the measures were appropriate.

Here is a list of special arrangements:

- Use test booklets in Braille and answer in Braille

- Enlarged test papers

- Extended test time

- Transcription of answers onto answer sheets

- Use of personal equipment

- Listening test exemption

- Seat position (e.g., in front of audio speaker, separate room, etc.)

- Other

One of the problems in establishing arrangements was how to judge various types and degrees of disabilities, as legislative, administrative, and educational systems for handicapped persons differ from country to country (Ueno and Ōsumi, 2008). Thus, the JLPT found a way to establish criteria not depending on the national or regional certificate where the examinees are, but by examining submissions of the actual conditions applied on the examinee at the current institution. It is estimated that examinees require the same or similar arrangements that have been made previously. The same goes for educational institutions of learners.

\subsection{Support systems at institutions abroad}

In this section we will look at the support systems at institutions in England and France, of which the dyslexic population is considerably high ${ }^{5}$ and, therefore, support systems are well organized in institutions. First, the UK ratified the Salamanca Statement ${ }^{6}$ in 1994, aiming for 'inclusive education', which is considered an approach to special support education, reaching out to the heterogeneity of learners and taking diversity as a starting point for education. The Special Education Needs and Disability

\footnotetext{
${ }^{5}$ Ten percent (10\%) of the population are dyslexic; $4 \%$ severely so. (British Dyslexia Association, Retrieved from http://www.bdadyslexia.org.uk/about)

${ }^{6}$ Retrieved from http://www.unesco.org/education/pdf/SALAMA_E.PDF
} 
Act (SENDA) 2001 requires educational support for LDs and dyslexia at schools and The Children and Families Act 2014 guarantees support of children with special educational needs or disabilities up to the age of 25 (Nishizawa in printing). On the other hand, in France, special support programs at universities are based on law on equal rights and opportunities, participation and citizenship of people with disabilities, ratified on February 11, 2005 (LOI n 2005-102 du 11 février 2005 pour l'égalité des droits et des chances, la participation et la citoyenneté des personnes handicapées), and Charter university / handicap (Charte universite / handicap) in 2012 (Ōshima, 2013). ${ }^{7}$ In both countries, domestic laws are well developed to support students with LDs and dyslexia at universities.

\section{Actual conditions and attitudes about LD and dyslexia in Japanese language education}

\subsection{Special support for foreign LD and dyslexic Japanese language learner at universities}

In this section we will especially look at the status of special support for LD and dyslexic students in Japan. Ikeda (2004) seems to be the first report that surveyed approximately 80 Japanese language teachers at universities, and then Imura (2007) about 130 teachers at universities in Japan regarding LD supports. Ikeda (2013) surveyed only 15 teachers in Japanese language schools but especially about support for dyslexic leaners. Table 1 (see next page) is a comparison of these three surveys.

These three surveys should not be compared short-sightedly, because the topic and the number of investigated teachers and categories of the answers differ from each survey. However, at least the table shows the trend of how Japanese teachers understand LDs and dyslexia. From the surveys, the ratio of language teachers who do not know about LDs and dyslexia at all has reduced in the past decade, and teachers with such knowledge are increasing, rising from $57 \%$ in 2001 to $81.04 \%$ in 2005 . The growing ratio seems to reflect the increased awareness that Japanese teachers gradually have acquired about LDs and dyslexia in the last decade.

\footnotetext{
${ }^{7}$ Corresponding to these laws in UK and France, Convention on the Rights of Persons with Disabilities, which was adopted by the United Nations in 2007, was ratified in 2015 after several years of necessary measures in domestic matters, and Act of Discrimination classification of Persons with Disabilities is going to be put into force in 2017.
} 
Table 1: Research on the recognition of dyslexia

\begin{tabular}{|c|c|c|c|c|c|c|}
\hline $\begin{array}{c}\text { Report, } \\
\text { year } \\
\text { and theme }\end{array}$ & $\begin{array}{c}\begin{array}{c}\text { Year of } \\
\text { the } \\
\text { research }\end{array} \\
\end{array}$ & Sampling & $\begin{array}{l}\text { Know very } \\
\text { well }\end{array}$ & $\begin{array}{l}\text { Know what } \\
\text { LD/dyslexia is }\end{array}$ & $\begin{array}{l}\text { Have heard } \\
\text { the term } \\
\text { LD/dyslexia }\end{array}$ & $\begin{array}{l}\text { Have never } \\
\text { heard about } \\
\text { LD/dyslexia }\end{array}$ \\
\hline $\begin{array}{l}\text { lkeda } \\
\text { (2004) } \\
\text { on LD }\end{array}$ & 2001 & $\begin{array}{l}81 \text { Japanese } \\
\text { teachers at } \\
\text { univ. in Japan }\end{array}$ & 4 (5\%) & 42 (52\%) & 31 (38\%) & $3(4 \%)$ \\
\hline \multirow[t]{2}{*}{$\begin{array}{l}\text { Imura } \\
(2007) \\
\text { on LD }\end{array}$} & \multirow[t]{2}{*}{2005} & \multirow[t]{2}{*}{$\begin{array}{l}132 \text { Japanese } \\
\text { teachers at } \\
\text { univ. in Japan }\end{array}$} & \begin{tabular}{|c} 
With teaching \\
experience \\
$30(22.72 \%)$ \\
\end{tabular} & \multirow[t]{2}{*}{68 (51.51\%) } & \multirow[t]{2}{*}{$13(9.84 \%)$} & \multirow[t]{2}{*}{9 (6.81\%) } \\
\hline & & & $\begin{array}{c}\text { Have } \\
\text { knowledge } \\
9(6.81 \%)\end{array}$ & & & \\
\hline $\begin{array}{l}\text { Ikeda } \\
\text { (2013) } \\
\text { on dyslexia }\end{array}$ & $\begin{array}{c}\text { Not } \\
\text { described }\end{array}$ & $\begin{array}{c}15 \text { Japanese } \\
\text { teachers in } \\
\text { Japan }\end{array}$ & \multicolumn{2}{|c|}{15 (100\%) } & $0(0 \%)$ & $0(0 \%)$ \\
\hline
\end{tabular}

More interesting, however, are teachers' attitudes about LDs and dyslexia on the following two points. Firstly, the knowledge about LDs and dyslexia that Japanese teachers have is not always correct: "LDs are often mixed with ADHD (attention deficit hyperactivity disorder) or developmental disorder" (Imura, 2007, p. 8) and "dyslexia is thought not to be hereditary" (Ikeda, 2013, p. 7) and so on. Language teachers answered that they have knowledge about LDs and dyslexia; however, it is not always based on positive knowledge, but instead on vague conjecture through the media or stories without foundation.

Secondly, the present status is reported that teachers obtain measures and supporting methods for LDs and dyslexia through their own experience, not within the institutional supporting division, and it remains unchanged in the past decade. Ikeda (2004) and Imura (2007) pointed out that the teachers learn by themselves how to support and arrange for LD learners through their trials and efforts. Ikeda (2013) reports that all 15 respondents recognize the needs of instruction on dyslexia in training courses for Japanese teachers. It shows that the institutional supporting system, that the JASSO reported is increasing, does not function to help them efficiently.

\subsection{Educational institutions in Japan and dyslexia}

Unfortunately, this is not the scene found only in Japanese language education. According to Hiroshima's survey (2007) of 75 teachers for special support education at elementary and secondary school, they answered that they do not have proper information about the mechanism of dyslexia: only $4 \%$ of them had already known about dyslexia and others had not known or understood properly. The teachers, as well as the Japanese language teachers, try to find better support measures at 
schools through their experiences without certain foundations. The present scene may be different from the survey in 2007, because the present status for LDs is changing every year as the new School Education Act was enforced in 2007 and LD and ADHD students, who had not previously been targeted for support, can now qualify for special support at school. However, at least in 2007, each teacher was isolated at school, and when faced with dyslexic students, searched independently for strategies without any organizational support; such is the case now in Japanese language education.

\subsection{Conclusions from these surveys}

In this section I will discuss future schemes of supporting dyslexic learners in Japanese language education, which can be obtained through the surveys.

First of all, they tell us that teachers need to have proper and accurate knowledge about dyslexia based on scientific and positive grounds. The media can help to diffuse information and understanding about dyslexia, but it is not enough for teachers to support dyslexic students. What they need is an understanding of the neurobiological mechanism that causes dyslexia, proven supports based on the mechanism, and teaching methods which should be effective on dyslexic students. Teachers are required to have knowledge about dyslexia before facing-dyslexic students in class so that they can identify and deal with the problem as soon as possible.-1 believe it is vital that teachers have some knowledge of dyslexia since it is based on a neurobiological deficit. I will discuss this in the next section.

Besides teachers' preparation for dyslexia, it is also essential that supporting divisions at educational institutions function properly. As shown in MEXT and JASSO surveys, it is true that the number of supporting divisions is increasing, but there is room for doubt whether they function properly for supported students, supporting teaching staff, as well. The supporting division at educational institutions should be a place, as is the case in England and France, to evaluate the status of students and provide the direction and methods necessary to solve-problems and allow for continued studies.

Additionally, cooperation among teachers tightens the supporting system. Dyslexic students at Japanese language institutions are enrolled in ordinary classes and study with other students. The special supports outside the regular classes are only a part of their studies, and this is not enough if only teachers for special supports teach and support them. Another reason that cooperation with other teachers is required is because teachers' lack of understanding of dyslexia can cause dyslexic students' to suffer from low self-esteem. Dyslexic students are usually not disabled in mental ability, nor lazy, but they do have neurobiological deficits in the phonological component. Attention and support with positive knowledge for all teachers leads the way to effective learning without absence of self-esteem, insecurity, pressure and feelings of alienation. 


\section{Discussion - why do we need perspective of dyslexia?}

Dyslexia is a learning difficulty that affects only a small percentage of Japanese language learners. So, why do teachers have to learn about dyslexia? Below are three beneficial points which dyslexia presents to Japanese language education.

\subsection{Neurobiological approach to reading-writing process}

The neurobiological approach, which is considered a basis for dyslexia, promotes better understanding of literacy and different processes underlying neural circuits. The process of phonological and semantic understanding may suggest more effective learning for language learners, as well as dyslexic learners. This leads teachers to reconsider their teaching methods, whether their ways to teach characters, words and their meanings are proper from the point of neurobiological mechanism. The neurobiological approach also gives another perspective to research how a learner recognizes characters, phrases, sentences and then texts, with regarding to understanding the meanings and listening the sounds.

Thus, the neurobiological approach may uncover different pathways of understanding of literacy, which will enable language teachers to design a different possible pathway of language learning. The approach should also suggest a way of teaching and dealing with characters in Japanese classes at the present when digital life with computer and smart phone makes us possible to live our lives without writing characters but with only recognizing then. The process and pathway may differ in Japanese language from in alphabetic language, but such a pathway underlying the neurobiological result should be effective for language education, which is inclusive rather than selective with potential consequences.

\subsection{Reform of Japanese language learning in teaching method and institutional system}

Dyslexic learners have, in the past, been labeled as 'lazy' and 'hindering' in the classroom. However, research on dyslexia uncovered neurobiological foundations, and language teachers can now design effective and more targeted interventions in language learning. It is an alternative way to achieve the same end goal for the acquisition of literacy. The methods in language learning based on linguistics research and teachers' experiences are undoubtedly effective, but the research results on dyslexia give us other efficient ways of literacy process underlying neural circuits. Here are two examples to prove one's literacy: the DAISY and a reading system on IDA homepage. First, the DAISY (Digital Accessible Information System) is a digital system for audio library which offers a recorded sound and a text synchronically colored with the voice. The second example, on the IDA homepage, provides a text and sound that one highlights the phrase or the sentence, and he can hear the sound. Those two digital methods help a person to reach to the end goal - to read and understand the meanings. Though they are aimed for dyslexic people and people with visual and 
hearing disabilities, they suggest new ways to learn a language to the field of language education.

Research on dyslexia also makes us reconsider supporting systems at language learning institutions. Previous research uncovers the status that inadequately organized supporting systems in language institutions do not serve as wellfunctioning tools for teachers trying to solve problems. Language institutions should improve their status under a nationally endorsed instruction program, so that dyslexic learners and teachers supporting them can learn and develop to the best of their abilities.

\subsection{Inclusive education and learner autonomy}

To reconsider learning methods and institutional systems leads us to reconsider the interaction and relationships between teachers and learners. To find better methods for a singular dyslexic learner leads us to consider inclusive education and learner autonomy, which is currently the strong stream in language education as in Tumposky (1982), Thanasoulas (2000) and others.

Inclusive education is an alternative thought to special education because it integrates learners with disabilities into regular society. Inclusive education, which is a basic thought of the Salamanca statement adopted in 1994, aims to enroll all children even those with disabilities, into mainstream schools and regular classes, unless there are compelling reasons for doing otherwise. With the shift of educational ideology, inclusive education became a reforming process of the whole education system to welcome diversity and to benefit all learners. Meanwhile, the integration of special education students and forced assimilation into regular classes has resulted in the oversight of some learners' particular needs and identities. Integration demands that all teachers be involved in supporting all learners in education, even in regular classes. Thus, knowledge of dyslexia is needed for all teachers to cooperate in supporting dyslexic learners.

When teachers are aware of learners' problems in learning, learning methods, goals of study and so on, it encourages learners' autonomy in learning. Though there is no room to discuss learners' autonomy in this paper, thinking about dyslexic learners allows teachers to reconsider teaching methods in which teachers teach leaners Japanese language in a class' and instead to think of each learner and his background as part of that learner's lifelong study. 


\section{Conclusion}

In this paper, we discussed the status of accepting dyslexic learners in Japanese language teaching and why Japanese teachers need to have a perspective of dyslexia. Potential dyslexic learners in Japanese language are very few, however, the perspective of dyslexia brings about both reform of Japanese language education and, as OECD mentioned, results in change 'more accurately conceptualized as an alternative developmental pathway' (OECD, 2007, p. 92). This results in the reform of institutional systems to support learners with disabilities or other problems and to investigate whether or not such systems are functioning properly. Dyslexia is a disability of the phonological component bound to semantic understandings, but includes future suggestions in widespread subjects.

\section{References}

British Dyslexia Association. About the British Dyslexia Association. Retrieved from http://www.bdadyslexia.org.uk/about-us.html

Hiroshima, S. (2007). Disurekushia ni tsuiteno rikaino genjō - kōkai kōza jukōsha o taishō ni shita ankeeto chōsa yori-(Analysis of Knowledge of Dyslexia and Dyslexic Children among School Teachers). Jinbun kagaku, 56 (1), 205-214. Faculty of Education, Gifu University. http://www.ed.gifu-u.ac.jp/kyoiku/info/zinbun/pdf/560115.pdf

Ikeda, N. (2013). Nihongokyōshi wa disurekushia o dō ninshiki shiteirunoka Nihongokyōin yōsei puroguramu kaihatsu no tameno kisokenkyū - (How do Japanese Instructors Recognize Dyslexia? - Basic Research for Development of Japanese Language Teacher Program. Nihongo kyōiku jissen kenkyū, 1, 1-15. Rikkyō University. http://www2.rikkyo.ac.jp/web/i7nobuko/2013/20131NI.pdf

Ikeda, N. \& Moritoki, N. (2013). Surovenia kyōwakoku ni okeru yomikaki shōgai shien seisaku no enkaku: Disurekusia no gakushūsha o taishō to shita nihongo kyōiku shien no kiso to shite (Supporting Learning Disabilities in Slovenia : Building a Social System for Japanese Language Learners with Dyslexia). Kotoba, bunka, komyunikeeshon, 5, 141-152. Rikkyō University. https://www.rikkyo.ac.jp/ibk/faculty/PDF/AA12405898_05_08.pdf

Ikeda, Y. (2004). Gakushūshōgai o motsu ryūgakusei no ukeire to shien (Accommodation Students with Learning Disabilities in a Japanese Language Program). Nihongo kyōiku, 120, 113-118. The Society for Teaching Japanese as a Foreign Language.

Imura, M. (2007). Gakushūshōgai o motsu ryūgakusei eno kojin, soshikiteki taiō ni kansuru ichikōsatsu (A Study on Individual and Systematic Accommodations for International Students with Learning Disabilities: A Comparison between Readiness of Host Universities and Student's Expectations). Center for Student Exchange journal, 10, 3-10. Hitotsubashi University. http://hermes-ir.lib.hitu.ac.jp/rs/handle/10086/14357 
Ishii, K. (2004). Yomikaki nomino gakushū konnan (disurekishia) eno taiōsaku

(Accomodation for dyslecsia). Science \& Technology Trends, December 2004. National Institute of Science and Technology Policy, MEXT. Retrieved from http://www.nistep.go.jp/achiev/ftx/jpn/stfc/stt045j/0412_03_feature_articles/2004 12_fa01/200412_fa01.html

Japan Foundation. (2013). Survey Report on Japanese-Language Education Abroad 2012. Kuroshio shuppan. Tokyo, Japan.

Japan Student Services Organization (JASSO). (2015). Daigaku, tankidaigaku, kōtō senmon gakkō ni okeru shōgai no aru gakuseino shūgaku shien ni kansuru jittai chōsa kekka hōkokusho (Survey Results on Learning Supports for Disabled Students at Universities, Colleges and Technical Colleges). Retrieved from http://www.jasso.go.jp/tokubetsu_shien/documents/chosa05_houkoku.pdf

Kavkler, M. (2002). Poročilo o delu društva za leto 2002. Retrieved from http://www.drustvobravo.si/web/index.php?option=com_phocadownload\&view=cat egory\&id=4\&/temid=40

Lerner, J. (1989). Educational interventions in learning disabilities. Journal of the American Academy of Child \& Adolescent Psychiatry, 28, 326-331.

Lyon, G. R., Shaywitz, S. E., \& Shaywitz, B. A. (2003). A definition of dyslexia. Annals of dyslexia, 53(1), 1-14.

Ministry of Education, Culture, Sports, Science and Technology in Japan (MEXT). (2003). Tūjō no gakkyū ni zaisekisuru tokubetsuna kyōikuteki shien o hitsuyō to suru jidō seito ni kansuru zenkoku jittai chōsa - Chōsa kekka (Survey Results of National Survey of Students who Require Special Educational Supports Enrolled in Regular Classes.

Retrieved from http://www.mext.go.jp/b_menu/shingi/chousa/shotou/018/toushin/030301i.htm

Ministry of Education, Culture, Sports, Science and Technology in Japan (MEXT). (2012). Tūjōno gakkyū ni zaisekisuru hattatsu shōgai no kanōsei no aru tokubetsuna kyōikuteki shien o hitsuyō to suru jidō seito ni kansuru chōsa kekkani tsuite. (On Result of Survey Related to Students that Require Special Educational Supports that might Developmental Disabilities Enrolled in Regular Classes). Retrieved from http://www.mext.go.jp/a_menu/shotou/tokubetu/material/_icsFiles/afieldfile/201 2/12/10/1328729_01.pdf

Nishizawa, K. (in printing). Disurekushia to nihongo kyōiku - eikoku ni okeru taiō to kadai-(Dyslexia and Japanese Language Education - Support and Problems in England -) Disurekushia gakushūsha ni taisuru kyōjuhō kaihatsu hōkokusho (Report on Development of Teaching Method on Dyslexic Learners). Grants-in-Aid for Scientific Research, No. 24652105.

Organisation for Economic Co-operation and Development (OECD). (2007). Understanding the Brain: The Birth of a Learning Science. OECD. MA, U.S.A. 
Ōshima, H. (2013). Furansu no daigaku ni okeru shōgai gakusei shien seisaku to disurekushia gakusei: Pari didoro daigaku no baai (Dyslexic Students and the French Policy toward University Students with Disabilities: Example of Paris Diderot University). Journal for the study of Japanese Language education practice, 1, 42-50. Rikkyō University. http://www2.rikkyo.ac.jp/web/i7nobuko/2013/20134HO.pdf, 15. 4. 2015

Shaywitz, S. (2003). Overcoming dyslexia: A new and complete science-based program for reading problems at any level. Knopf, New York, U.S.A.

Shaywitz, S. E., \& Shaywitz, B. A. (2004). Reading disability and the brain. Educational Leadership, 61(6), 6-11.

Thanasoulas, D. (2000). What is Learner Autonomy and How Can It Be Fostered? The Internet TESL Journal, Vol. VI, No. 11.

Tumposky, N. (1982). 'The learner on his own'. In M. Geddes and G. Sturtridge (eds.). Individualisation, 4-7. London: Modern English Publications.

Ueda, K. (2003). Nihongo nōryoku shiken ni okeru shōgaisha juken tokubetsu sochi taiō no genjō to kadai (A Report on "Non-standard Testing Arrangements for People with Disabilities"). Nihongo kyōiku sentaa kiyō, 13, 99-115. Kokusai kōryū kikin (The Japan Foundation).

Uno, A., Haruhara, N., Kaneko, M. \& Wydell, T. N. (2006). Shōgakusei no yomikaki keisan sukurīningu kensa - Hattatsusei yomikaki shōgai (hattatsusei dyslexia) kenshutsuno tameni (Screening Test of Reading and Writing for Japanese Primary School Children). Interuna shuppan. Tokyo, Japan.

Ueno, K. and Ōsumi, A. (2008). Nihongo nōryoku shaken ni okeru hattatsusei disurekushia (shikiji shōgai) eno tokubetsu sochi (A Report on Special Testing Arrangements for People with Developmental Dyslexia on Japanese Language Proficiency Test). Kokusai kōryūkikin nihongo kyōiku kiyō, 4, 157-167. Kokusai kōryū kikin (The Japan Foundation).

United Nations Educational, Scientific and Cultural Organization (UNESCO). (2005). Guidelines for Inclusion: Ensuring Access to Education for All. Paris, France. Retrieved from http://unesdoc.unesco.org/images/0014/001402/140224e.pdf 
